tions. One ${ }^{22}$ states that: ". . . any proposals for softening the water supply in any part of the country [UK] should be considered in the light of knowledge about the observed positive relationship between the death rate from ischaemic heart disease and the softness of the local water supply." The second ${ }^{23}$ states: "Where domestic water softeners are used, it might be prudent for drinking-water to be taken from the mains supply." Both are counsels for inaction, which is the most our present knowledge should allow.

${ }^{1}$ Schroeder, H A, Fournal of the American Medical Association, 1960, 172 , 1902.

Schroeder, H A, Fournal of Chronic Diseases, 1960, 12, 568.

3 Morris, J N, Crawford, M D, and Heady, J A, Lancet, 1961, 1, 860.

${ }^{4}$ Morris, J N, Crawford, M D, and Heady, J A, Lancet, 1962, 2, 506.

${ }^{5}$ Heyden, S, Fournal of Chronic Diseases, 1976, 29, 149.

${ }^{6}$ Crawford, M D, Gardner, M J, and Morris, J N, Lancet, 1968, 1, 827.

7 Anderson, T W, Le Riche, W $\mathrm{H}$, and Mackay, J S, New England fournal of Medicine, 1969, 280, 805.

8 Tyroler, $\mathrm{H} \mathrm{A}$, in The Community as an Epidemiological Laboratory, eds I I Kessler and M L Levin, p 100. Baltimore, Johns Hopkins, 1970.

${ }^{9}$ Lindeman, R D, and Assenzo, J R, American fournal of Public Health, 1964, 54, 1071.

${ }^{10}$ Allwright, S P A, et al, Lancet, 1974, 2, 860.

11 Comstock, G W, American fournal of Epidemiology, 1971, 94, 1.

12 Mulcahy, R, fournal of the Irish Medical Association, 1964, 55, 17.

${ }^{13}$ Elwood, P C, Abernethy, M, and Morton, M, Lancet, 1974, 2, 1470.

${ }_{14}$ Roberts, C J, and Lloyd, S, Lancet, 1972, 1, 1091.

${ }_{15}$ Gardner, M J, Crawford, M D, and Morris, J N, British fournal of Preventive and Social Medicine, 1969, 23, 133.

${ }^{16}$ Dudley, E F, Beldin, R A, and Johnson, B C, fournal of Chronic Diseases, $1969,22,25$.

1: West, R R, Lloyd, S, and Roberts, C J, British fournal of Preventive and Social Medicine, 1973, 27, 36.

18 West, R R, and Lowe, C R, International fournal of Epidemiology, 1976, 5, 195.

${ }^{19}$ Anderson, T W, et al, Canadian Medical Association fournal, 1975, 113, 199

${ }^{20}$ Chipperfield, B, et al, Lancet, 1976, 1, 121.

21 Campos, A T, Lancet, 1976, 1, 1244.

22 DHSS, Report on Health and Social Subjects 7, Diet and Coronary Heart Disease. London, HMSO, 1974.

${ }^{23}$ Report of a Joint Working Party of the Royal College of Physicians of London and the British Cardiac Society, Fournal of the Royal College of Physicians, 1976, 10, 213; Royal College of Physicians and British Cardiac Society, British Medical fournal, 1976, 1, 881.

\section{Is the cholera pandemic waning?}

The current pandemic of cholera, if not on the decline, may be at least becoming stabilised. ${ }^{1}$ In 1975 the number of countries notifying cholera was the smallest since 1970. The disease extended to only one new country in Africa and only one in Asia. The trend seems generally downwards. In 1970 cholera was reported by 36 countries with a total of 155555 cases. In 1975 the score was 29 countries and 87475 cases. The drop in numbers of countries and cases was most notable in Africa. On the whole the same countries remained infected in Asia. In Europe cholera continued in limited "epidemic" form in Portugal and there were some possibly "endemic" cases in France and Spain. Cases were imported into Britain and Italy.

This fall is encouraging, especially in view of the improvement in national and international surveillance which has brought some sort of reality to the figures quoted. Earlier in the pandemic reported outbreaks sometimes led to drastic long-term and financially damaging measures by neighbouring countries, including restriction of imports and closure of ports and airports; and this resulted in resistance to reporting the presence of the disease and so made world figures unrealistic. The introduction of International Health Regulations in 1969 in place of the more rigid International Sanitary Regula- tions seems to have reduced the fear of unwarranted sanctions. ${ }^{2} 3$

The current pandemic has resulted from the spread of the El Tor vibrio, discovered in 1906 in a village of the same name in the Sinai Peninsula. For many years regarded as a maverick, and not included in the WHO list of choleraproducing vibrios, the organism eventually reappeared in 1938 as the cause of a mild cholera-like disease in Sulawesi, and cases were reported in Java and Singapore during the second world war. A decade later the new vibrio spread rapidly throughout South-east Asia. In 1961 there were over 10000 cases, many severe, in the Philippines. By 1963 Thailand, the Khmer Republic, Vietnam, Hong Kong, Burma, India, and both Pakistans became affected. In 1966 the disease appeared in Iraq and Syria and then spread westward, reaching eastern Europe, North Africa, and Africa south of the Sahara (probably for the first time in history). Imported cases began to appear in western Europe, including Britain, and sporadic outbreaks occurred in other countries, especially Portugal.

Except in Bangladesh the El Tor organism now occupies the former endemic areas of the classical vibrios, which have otherwise practically disappeared. The spread of the vibrio has been encouraged by the increasing ease and frequency of contacts in infected areas. For the initial transfer over long distances the aeroplane has been the major agent. Over short distances the ship has also played its part, as in the (presumed) transfer from Sulawesi to Java.

Once established, the infection has spread within a country and to its neighbours through movements of people across uncontrolled terrain, national borders, and along rivers and coastal areas by fisherman, as in West Africa. The establishment of the disease depends on the coexistence of an insanitary environment and a population ignorant of hygiene. These two factors are common to the spread of all vibrios, but the El Tor organism has certain advantages over its rivals. Once it reaches receptive insanitary areas it tends to remain in them and may well stay there until sanitation improves sufficiently; and so new endemic areas are set up. The new vibrio is more persistent in the human body than the others and is commonly excreted in the faeces for two to three weeks after infection, whether or not accompanied by symptoms. There are also occasional chronic carriers, who are not found with the classical infections.

Clinical effects may be as severe as in any other form of cholera, or they may be mild or absent. Huwever, the patient, the convalescent, and the silent case all excrete the organism. Modern methods of treatment are excellent if offered early, but in large areas of the developing world, where cholera is most frequent, treatment is often unavailable. Where poverty, inaccessibility, and ignorance reign, the death rate is high.

In 1976 cholera is still very much with us, spread across the world, except, most remarkably, in the Americas-a possible pointer to control elsewhere. In contrast to our control of smallpox we have not yet got the weapons to eradicate cholera. We certainly cannot rely on the present inefficient vaccine. In the long run-and it may be a very long run-the final answer must be to make receptive areas ununreceptive by transformation of their sanitation. This is a problem for medical and health education and the provision and proper use of national and international funds.

\footnotetext{
1 World Health Organisation, Weekly Epidemiological Record, 1976, 51, 137.

2 World Health Organisation, International Health Regulations, 1969, 2nd edn. Geneva, World Health Organisation, 1974.

3 World Health Organisation, International Sanitary Regulations, 1951, annotated ed. Geneva, World Health Organisation, 1957.
} 